\title{
In vitro digestibility of globulins from sapucaia (Lecythis pisonis Camb.) nuts by mammalian digestive proteinases
}

Digestibilidade in vitro de globulinas das amêndoas de sapucaia (Lecythis pisonis Camb.) por proteinases digestivas de mamíferos

\author{
Sandra Maria Silveira DENADAI ${ }^{1}$, Priscila Aiko HIANE², Sergio MARANGONI ${ }^{3}$, Paulo Aparecido BALDASSO ${ }^{3}$, \\ Ana Maria Rauen de Oliveira MIGUEL ${ }^{4}$, Maria Lígia Rodrigues MACEDO ${ }^{2 *}$
}

\begin{abstract}
Sapucaia (Lecythis pisonis Camb.) raw nuts collected from Brazil were analyzed to determine the proximate composition, amino acid profile of protein fractions, in vitro protein digestibility and antinutritional factors in order to evaluate their potential as a protein alimentary complement. The nuts contained adequate amounts of essential amino acids, fatty acids and minerals. In the present study, no hemagglutinating or inhibitory activities were observed in any of the samples investigated, indicating low or non-detectable levels of proteinase inhibitors or lectins in the samples. In vitro digestibility of in natura and heated nut globulins by mammalian digestive proteinases was carried out using trypsin + chymotrypsin + peptidase, with resulting mean values of approximately 70.30 and $71.35 \%$, respectively. Taken together, the results suggest that sapucaia nuts may provide a new source of protein to use as a potential nutritional agent.

Keywords: protein digestibility; antinutritional factors; globulins; proteinases; Lecithys pisonis.
\end{abstract}

\section{Resumo}

Amêndoas cruas de Sapucaia (Lecythis pisonis Camb.) colhidas no Brasil foram analisadas para se determinar a composição centesimal, o perfil de aminoácidos de suas proteínas, a digestibilidade protéica in vitro e a presença de fatores antinutricionais, para avaliar o seu potencial como complemento alimentar protéico. As amêndoas apresentaram quantidades adequadas de aminoácidos essenciais, ácidos graxos e minerais; no entanto, baixo teor de fibra foi observado. No presente estudo, a presença de lectinas ou inibidores de proteinases, quando detectada, apresentou baixos níveis. A digestibilidade in vitro de globulinas, in natura ou aquecidas, por proteinases digestivas de mamíferos foi realizada utilizando-se tripsina + quimotripsina + peptidase, obtendo-se valores aproximados de 71,5 e 73,5\%, respectivamente. Estes resultados sugerem que as amêndoas de sapucaia podem ser utilizadas como complemento alimentar de proteínas, sendo um potencial agente nutricional.

Palavras-chave: digestibilidade protéica; fatores antinutricionais; globulinas; proteinases; Lecithys pisonis.

\section{Introduction}

Plants offer an enormous variety of macro and micronutrients for human consumption. The value of plant proteins in supplying the protein needs in developing countries has been recognized in recent years. Furthermore, fruit, seeds, nuts and almonds from regional native plants have been used to complement the diet of indigenous populations and animal feeding ${ }^{2,33}$ as they are as rich in proteins, carbohydrates, lipids, vitamins and minerals as legume grains ${ }^{37}$.

Brazilian flora has many native fruit-bearing forest species whose nuts and seeds are good sources of nutrients. Despite this diversity, nutrient intake in the diet of the Brazilian population can be poor, lower than the amounts required to be healthy.

Recebido para publicação em 19/7/2006

Aceito para publicação em 18/7/2007 (001797)

Departamento de Morfofisiologia, Centro de Ciências Biológicas e da Saúde,

Universidade Federal de Mato Grosso do Sul - UFMS,

Campo Grande - MS, Brasil

Departamento de Tecnologia de Alimentos,

Centro de Ciências Biológicas e da Saúde,

Universidade Federal de Mato Grosso do Sul - UFMS,

CP 549, CEP 79070-900, Campo Grande-MS, Brasil,

E-mail:bioplant@terra.com.br

Departamento de Bioquímica, Instituto de Biologia,

Universidade de Campinas - UNICAMP, Campinas - SP, Brasil

4 Centro de Química de Alimentos e Nutrição Aplicada

Instituto de Tecnologia de Alimentos, Campinas, SP, Brasil

*A quem a correspondência deve ser enviada
The search for alternative, nutritionally suitable and affordable food sources is thus highly desirable. The chemical composition and nutritional value are yet to be studied in many of the native species in Brazilian regions, although regional fruit, which was recently investigated, has been shown to be a good source of nutrients such as amino acids, sugars, fats, vitamins and fibers ${ }^{18,19}$. Among the edible species consumed in some regions of Brazil is the sapucaia (Lecythis pisonis Camb.), locally known as 'cumbuca-de-macaco', among other names. Native to Brazilian rainforests, the sapucaia is found in the Atlantic forest and in the Amazon region ${ }^{34}$. Its aromatic, sweet-tasting, oleaginous nuts can be consumed raw, boiled or roasted.

Before products of plant origin can be indicated to use as food complements, mainly as proteins sources, investigations should be conducted to determine the amino acid composition of their proteins and protein digestibility, as well as the presence of antinutritional factors. While the amino acid proportionality pattern of a protein is probably the most important determinant of protein quality, digestibility of protein and bioavailability of its constituent amino acids are the next most important factors ${ }^{8}$. Differences in protein digestibility may arise from inherent differences in the nature of food protein, from the presence of non-protein constituents, which may modify digestion, from the presence of antiphysiological factors or from processing conditions that alter the release of amino acids from proteins by enzymatic processes. However, digestibility still provides a satisfactory rate of protein use $\mathrm{e}^{8}$. 
In addition, high levels of insoluble fiber and high concentrations of antinutritional factors in diets are also responsible for poor digestibility of proteins ${ }^{14}$. Food and feed products may contain a number of antinutritional factors that may adversely affect protein digestibility and amino acid availability ${ }^{26}$. Inhibitory proteinases, abundant in the plant kingdom, are proteins that can inhibit trypsin, chymotrypsin, amylase, and carboxypeptidase activities ${ }^{11,13,28}$. Chronic ingestion of residual levels of antinutritional factors is unlikely to pose risks to human health.

Most animal proteins are well digested, resulting in efficient absorption of amino acids. In contrast, plant proteins are not usually well digested, and are thus nutritionally inferior. The value of plant proteins in supplying the protein needs in developing countries is well acknowledged. If some of the peptidic bonds fail to be hydrolyzed in the digestive process, part of the protein content is excreted in the feces or altered into metabolic products by intestinal microorganisms in the large intestine ${ }^{33}$. Good plant protein sources are essentially plant foodstuffs whose proteins are well digested.

Most studies designed to provide answers to questions related to the nutritional quality of plant proteins have focused on proteins in the globulin fraction. Globulins are globular proteins that are widely distributed throughout the plant and animal kingdoms. They are soluble in water or in dilute salt solutions. Globulins are involved in transporting a variety of substances, including lipids, hormones, and inorganic ions, in addition to playing a role in the immune system. They are present in seeds in high amounts as storage proteins, and are also found in fractions of antinutritional factors ${ }^{2}$. They have structural and enzymatic functions and are important in the germination process ${ }^{33}$.

Because the proteins of sapucaia nuts have not been previously characterized, the objective of this work was to study in vitro the action of mammalian proteinases-trypsin, chymotrypsin, and pepsin-on globulins and to determine the nutritional value of dry mature sapucaia nuts.

\section{Materials and methods}

\subsection{Material}

Nuts were obtained from dry mature sapucaia fruit collected from native trees at Estação Experimental de Santa Rita do Passa Quatro, SP at the Instituto de Pesquisa e Estudos Florestais do Estado de São Paulo, Brazil.

\subsection{Preparation of defatted meal}

The nuts were ground in a Delta Ultrassônico grinder (Delta, São Paulo, SP, Brazil) and pulverized to a homogenous powder, which was named whole meal. The whole meal was defatted with petroleum ether PA $\left(40-60{ }^{\circ} \mathrm{C}\right)$ in a Soxhlet extractor (Sebelin TE-188, TECNAL, São Paulo, SP, Brazil) for 24 hours. After extraction, the ether was evaporated at $105^{\circ} \mathrm{C}$ for 4 hours. The meal was again triturated and pulverized, resulting in a very fine powder that was called defatted meal, which was used as the source of proteins in all the experiments.

\subsection{Fatty acid composition}

Fatty acid composition of the lipid fraction was obtained after methyl etherification by a procedure described by HARTMAN and $\mathrm{LAGO}^{16}$. Identification and quantification were carried out using gas-liquid chromatography and flame ionization detection, according to the procedure outlined by FIRESTONE ${ }^{9}$ and HORWITZ ${ }^{22}$.

\subsection{Mineral content}

Micro and macromineral contents were determined in the Animal Nutrition Laboratory of EMBRAPA, Campo Grande, MS, Brazil, and the analysis was conducted according to the methodology described by SALINAS and GARCIA ${ }^{32}$, involving organic digestion with acids. Manganese, zinc, copper, magnesium, and iron contents were determined using an atomic absorption spectrophotometer. Sodium and potassium were determined by flame photometry and phosphorus and calcium by visible-light spectrophotometry.

\subsection{Proximate composition}

\section{Moisture}

The moisture content of the whole meal was determined by stove drying at $105{ }^{\circ} \mathrm{C}$ for approximately 4 hours according to methods described in the analytical norms of INSTITUTO ADOLFO LUTZ24.

\section{Total sugar}

The total sugar was determined by the reduction method using Fehling's reagent, according to the procedure described in the norms of INSTITUTO ADOLFO LUTZ ${ }^{24}$.

Ash

Ash (fixed mineral residue) was determined according to $\mathrm{AOAC}^{3}$. The total fiber was estimated by differences.

\section{Protein}

The protein content was measured with the procedure developed by BRADFORD ${ }^{4}$ with bovine serum albumin (BSA) as the protein standard and by total nitrogen content (\%) according to the Kjeldahl method described in $\mathrm{AOAC}^{3}$ and multiplied by a factor of 6.25 .

\subsection{Fractionation of meal proteins}

The nut protein fractions used in the present study namely, albumins, globulins, prolamins, glutelins and residue were prepared according to an extraction procedure with $\mathrm{NaCl}$, ethanol, and $\mathrm{NaOH}^{27}$. Fifteen-gram portions of nut flour were extracted with $150 \mathrm{~mL}$ of $4 \% \mathrm{NaCl}$ for 1 hour. The slurry was centrifuged at $17000 \mathrm{x}$ g for 30 minutes at $4{ }^{\circ} \mathrm{C}$ and the supernatant was then dialyzed against distilled water for albumin and globulin separation. The residue of the salt extraction was suspended in $70 \%$ ethanol for 1 hour and again centrifuged as described above to obtain prolamins. The alcohol-insoluble pellet was 
suspended in $100 \mathrm{mM} \mathrm{NaOH}$ and extracted for 1 hour. Glutelins were then obtained by centrifugation as described above. All the fractions plus the final insoluble residue were recovered by dialysis and freeze-drying.

\subsection{SDS-PAGE-polyacrylamide gel electrophoresis}

This method was carried out using a LAEMMLI system (1970). The proteins used as molecular mass standards were: phosphorylase b (94 kDa), bovine serum albumin (66 kDa), ovalbumin (45 kDa), carbanic anhydrase (30 kDa), soybean trypsin inhibitor (20 kDa), and $\alpha$-lactoglobulin (14.2 kDa).

\subsection{Hemagglutination assay}

Hemagglutination assays were done in microtiter U-plates using serial dilutions with $50 \mu \mathrm{L}$ volumes of $105 \mathrm{mM} \mathrm{NaCl}$. A $50 \mu \mathrm{L}$ volume of a $2 \%$ suspension of type A human erythrocytes was added and, after 1 hour at room temperature, the results were read. The hemagglutination titer corresponding to the reciprocal of the highest dilution showing hemagglutination was defined as one hemagglutination unit ${ }^{11}$.

\subsection{Inhibitory activity assay}

Bovine pancreatic trypsin and bovine pancreatic chymotrypsin were used for the enzymatic assays. Trypsin-like activities were assayed using $\mathrm{N}$ - $\alpha$-benzoyl-DL-arginine $p$-nitroanilide (BApNA) as a substrate. Chymotrypsin-like activities were assayed using N-benzoyl-L-tyrosine $p$-nitroanilide (BTpNA) as substrate $^{27}$. In a standard assay, a reaction mixture contained $50 \mu \mathrm{L}$ of each enzyme extract, reaction buffer ( $100 \mathrm{mM}$ Tris- $\mathrm{HCl}$ buffer, $\mathrm{pH} 8.0$ ), and $50 \mu \mathrm{L}$ of $1 \mathrm{mM}$ substrate to a final volume of $500 \mu \mathrm{L}$. The reaction was stopped by adding $200 \mu \mathrm{L}$ of $30 \%$ acetic acid. The release of $p$-nitroaniline groups was measured spectrophotometrically at $410 \mathrm{~nm}$. The proteinase inhibitor was assayed by preincubating $50 \mu \mathrm{L}$ of fraction at concentrations ranging from 25 to $200 \mu \mathrm{g}$ with $50 \mu \mathrm{L}$ of proteinase and $350 \mu \mathrm{L}$ of reaction buffer at $37{ }^{\circ} \mathrm{C}$ for 15 minutes. The reaction was started by adding the substrate and was performed as described above. The remaining activity was expressed as the percentage of enzymatic activity in the absence of an inhibitor.

\subsection{Amino acid composition}

Amino acid analysis was performed on a PicoTag amino acid analyzer (Waters) as described by HENRIKSON and MEREDITH ${ }^{17}$. One nanomole of protein fraction was hydrolyzed in $6 \mathrm{M} \mathrm{HCl} / 1 \%$ phenol at $106{ }^{\circ} \mathrm{C}$ for 24 hours. The hydrolyzed was reacted with $20 \mu \mathrm{L}$ of fresh derivatization solution (methanol : triethylamine : water : phenylisothiocyanate, $\left.7: 1: 1: 1,{\mathrm{v} . \mathrm{v}^{-1}}^{-1}\right)$ for 1 hour at room temperature. After pre-column derivatization, phenylisothiocyanate (PTC) amino acids were identified on a reverse-phase HPLC column by comparing their retention times to those of standard PTC amino acids (Pierce). Cysteine residues were quantified as cysteic acid.

\subsection{Purification of globulins}

Globulins were prepared from sapucaia nuts by the procedure described by MACEDO ${ }^{27}$. Ground meals, extracted with
$50 \mathrm{mM}$ borate buffer at $\mathrm{pH} 8.0$ for $30 \mathrm{~min}$ at room temperature, were centrifuged ( 30 minutes at $8000 \times$ g at $5{ }^{\circ} \mathrm{C}$ ) and the supernatant proteins were fractioned by ammonium sulfate precipitation. The $70-90 \%$ saturation fraction was dialyzed against water, freeze-dried, and applied to a Sephacryl S-200 column ( $3 \mathrm{~cm} \times 50 \mathrm{~cm}$ ) equilibrated and eluted with the same buffer used for extraction. The globulin-rich fractions were recovered using an ion-exchange chromatography on a DEAE-Sepharose column $(2 \mathrm{~cm} \times 20 \mathrm{~cm}$ ), equilibrated with $50 \mathrm{mM}$ Tris- $\mathrm{HCl}$ at $\mathrm{pH} 8.0$ and eluted with a $\mathrm{NaCl}$ gradient ( $100 \mathrm{mM}$ ) in the same buffer. Globulins were dialyzed in water and freeze-dried.

\subsection{In vitro digestibility of globulins}

Globulins were dissolved in a $100 \mathrm{mM}$ phosphate buffer at pH 6.0 at a $0.5 \mathrm{mg} \cdot \mathrm{mL}^{-1}$ concentration. Globulins $(250 \mathrm{~mL}$ aliquots) were separately assayed for digestion by $10 \mathrm{~mL}$ of pepsin (25 mg. $\mathrm{mL}^{-1}$ in $50 \mathrm{mM} \mathrm{HCl}$ ), trypsin $\left(25 \mathrm{mg}^{-\mathrm{mL}^{-1}}\right.$ in $100 \mathrm{mM}$ phosphate buffer, pH 7.0), or chymotrypsin $\left(25 \mathrm{mg} \cdot \mathrm{mL}^{-1}\right.$ in $100 \mathrm{mM}$ phosphate buffer, $\mathrm{pH} 7.0$ ), at $37^{\circ} \mathrm{C}$ for periods of 15 minutes, 30 minutes, 1,2 , and 4 hours. The substrate-toproteinase ratio was 20:1. Adding a 10\% SDS solution stopped the digestion ${ }^{2}$. The enzymes used for the globulin digestibility assay were purchased from the Sigma Chemical Co. (St. Louis, MO, USA).

\subsection{Multienzymatic assays}

Globulin digestibility was assayed by the in vitro method described by HSU et al. ${ }^{23}$. Calculated control (casein) and samples were weighed, dissolved in $10 \mathrm{~mL}$ of distilled water and refrigerated at $5{ }^{\circ} \mathrm{C}$ for 1 hour. The globulin-containing samples and enzymes were all adjusted to $\mathrm{pH} 8.0$ at $37^{\circ} \mathrm{C}$. Globulin digestibility was determined by digesting the protein-containing sample with a multienzyme mixture-trypsin (porcine pancreatic trypsin-Type IX) with 14190 BAEE units/mg protein; $\alpha$-chymotrypsin (bovine pancreatic chymotrypsin-Type II), 60 units/mg powder; and peptidase (porcine intestinal peptidase-Grade III), 40 units/g powder-at $37^{\circ} \mathrm{C}$. A pH drop from 8.0 in the samples was recorded after 20 min of incubation. Globulin digestibility was calculated according to the regression equation $(\mathrm{Y}=234.84-22.56 \mathrm{X}$, where $\mathrm{Y}=\%$ digestibility, $\mathrm{X}=\mathrm{pH}$ drop) described by $\mathrm{HSU}^{23}$. The assays were performed using native and heated globulins.

\subsection{Statistical tests}

The results were expressed as mean \pm S.D., the level of significance was $5 \%(\mathrm{p}<0.05)$, when applicable. The data were analyzed using an analysis of variance (ANOVA) (general linear models or GLM procedure) ${ }^{30}$.

\section{Results and discussion}

\subsection{Proximate composition}

Table 1 shows the proximate composition and total calorie content ( $\mathrm{kcal} 100 \mathrm{~g}^{-1}$ ) of the whole meal. The lipid and protein contents are in accordance with values found in the 
literature (60.61 and $20.47 \%$, respectively) with $L$. pisonis seeds collected in Brazil, revealing a high energy content $\left(645.05 \mathrm{kcal} .100 \mathrm{~g}^{-1}\right)^{10,38,39}$.

According to MELLO et al. ${ }^{29}$, the cashew nut (Anacardium occidentale L.) contains $46.3 \%$ of total lipids and $24 \%$ of total carbohydrates; the carbohydrate content is significantly higher than that found in sapucaia of this work and of that reported by other authors ${ }^{38,39}$. However the amount of proteins found for cashew nuts $(22 \%)$ is similar to the value of the studied sapucaia.

Lipid contents of the Pará nuts (Bertholletia excelsa) (69.3\%) are higher than those of the sapucaia (60.61\%). However, the protein (16.4\%), carbohydrate (3.2\%) and fiber (4.6\%) contents are lower in the Pará nuts ${ }^{7}$ than in the sapucaia nuts, when compared to the values contained in Table 1.

Table 1. Proximate composition of sapucaia (Lecythis pisonis Camb.) nuts, expressed as g. $100 \mathrm{~g}^{-1}$ of raw matter.

\begin{tabular}{lc}
\hline \multicolumn{1}{c}{ Component } & \multicolumn{1}{c}{ Results* } \\
\hline Moisture & $5.04 \pm 0.03$ \\
Ash & $3.80 \pm 0.01$ \\
Crude lipid (ether extract) & $60.61 \pm 0.33$ \\
Total sugars & $4.42 \pm 0.23$ \\
Protein (N x 6.25) & $20.47 \pm 0.38$ \\
Total dietary fiber (by difference) & 5.67 \\
Total calorie content (kcal.100 $\left.\mathrm{g}^{-1}\right)^{* *}$ & $645.05 \pm 2.07$
\end{tabular}

*Mean values \pm standard deviation of triplicate determinations; and ${ }^{* *}$ Total calorie content was calculated with these factors: 4 for protein and sugars and 9 for lipids according to $\mathrm{FAO} / \mathrm{WHO}^{8}$.

\subsection{Fatty acid composition}

The fatty acid profile of the oils analyzed (Table 2 ) indicates a high content of unsaturated acids (monounsaturated, $34.22 \%$; polyunsaturated, $42.73 \%$; omega $3,0.19 \%$ ) and a predominance of linoleic (42.54\%) and oleic acids (33.94\%). The concentration of linoleic acid is in accordance with the levels recommended in BRAZIL $^{6}$ and by the AOCS ${ }^{3}$ for peanut oil (Brazil, 13.0-45.0\%; AOCS, 14.0-43.0\%).

Sapucaia nuts were found to be an excellent source of linoleic acid, an essential fatty acid. Moreover, their high lipid content and high level of oil unsaturation indicate their potential use for human consumption, in addition to being a good source of calories in nutritional diets; the data obtained are similar to the values found in the literature ${ }^{38,39}$. Regarding the quality of oils, the acid contents were within the international standards for the processing of crude vegetable oils for human consumption $^{38}$.

Comparing the sapucaia nuts to fruit nuts from the Palmae family, the bocaiúva seeds (Acrocomia aculeata (Jacq.) Lodd.) ${ }^{19}$ showed monounsaturated fatty acids (42.5\%) and saturated fatty acid $(49.7 \%)$ values higher than those found for sapucaia nuts, in this study.

Linoleic acid contents in the sapucaia nuts $(42.54 \%)$ are high when compared to values found for cashew nut $(19.6 \%)^{7}$.
Table 2. Lipid contents and main fatty acid composition of sapucaia (Lecythis pisonis, Camb.) nuts, expressed as g. $100 \mathrm{~g}^{-1 *}$

\begin{tabular}{lc}
\hline \multicolumn{1}{c}{ Fatty acid } & Results \\
\hline Lauric $(\mathrm{C} 12: 0)$ & 0.10 \\
Miristic $(\mathrm{C} 14: 0)$ & 0.10 \\
Palmitic $(\mathrm{C} 16: 0)$ & 12.14 \\
Palmitoleic $(\mathrm{C} 16: 1 \omega 7)$ & 0.19 \\
Stearic $(\mathrm{C} 18: 0)$ & 6.31 \\
Oleic $(\mathrm{C} 18: 1 \omega 9)$ & 33.94 \\
Linoleic $(\mathrm{C} 18: 2 \omega 6)$ & 42.54 \\
Cis-11-eicosanoic $(\mathrm{C} 20: 1 \omega 11)$ & 0.10 \\
Alpha linolenic $(\mathrm{C} 18: 3 \omega 3 \alpha)$ & 0.19 \\
\hline Saturated & 18.64 \\
Monounsaturated & 34.22 \\
Polyunsaturated & 42.73 \\
$\quad$ Omega 3 & 0.19 \\
$\quad$ Total trans-isomers & $\mathrm{ND}$ \\
\hline
\end{tabular}

${ }^{*}$ Area $\mathrm{X}$ conversion factor $\mathrm{F}\left(\mathrm{F}=0.956\right.$, according to HOLLAND $\left.{ }^{21}\right)$; and ${ }^{* *} \mathrm{ND}$ : not detected (detection limit $\left.=0.01 .100 \mathrm{~g}^{-1}\right)$.

\subsection{Mineral composition}

The mineral composition (macro and microminerals) of the nuts is shown in Table 3. Compared with the recommended dietary allowances for adults ${ }^{35,36}$, sapucaia nuts presented high values of nutritionally important minerals required in the human diet.

High levels of $\mathrm{Cu}, \mathrm{Mn}, \mathrm{P}, \mathrm{Mg}$, Fe and $\mathrm{Zn}$ were found in sapucaia nut samples, and $100 \mathrm{~g}$ of this nut may provide more than $30 \%$ of each mineral dietary recommendation intake for adults. Thus, it was classified here as a food rich in these minerals; the levels of $\mathrm{Cu}$ and $\mathrm{Mn}$ are 3.5 times higher than the dietary reference intake; and regarding the $\mathrm{K}$ content, the studied sapucaia nut can be classified as a source of this mineral, for male adults ${ }^{5,35,36}$.

Comparing the data obtained in this study to the data from papers with L. pisonis seeds (sapucaia) collected in Brazil ${ }^{38,39}$, high levels of $\mathrm{Cu}$ and significant quantities of $\mathrm{Zn}$ and $\mathrm{Mn}$ were also observed by other authors.

Table 3. Macro- and micromineral contents ${ }^{\mathrm{a}}$ of sapucaia (Lecythis pisonis, Camb.) nuts.

\begin{tabular}{ccc}
\hline Elements & Sapucaia & Reference $^{\mathrm{b}}$ \\
\hline $\mathrm{Na}$ & \multicolumn{1}{c}{$\mathrm{mg}^{-1}$} & mg.d \\
\hline $\mathrm{Fe}$ & $32.65 \pm 1.36$ & 1,200 \\
$\mathrm{Mn}$ & $80.69 \pm 2.20$ & 8 \\
$\mathrm{Zn}$ & $40.37 \pm 0.38$ & 2.3 \\
$\mathrm{Cu}$ & $32.76 \pm 1.14$ & 11 \\
& $\mathrm{mg} \cdot \mathrm{g}^{-1}$ & 0.9 \\
\hline $\mathrm{Ca}$ & $1.72 \pm 0.02$ & 1,200 \\
$\mathrm{Mg}$ & $2.79 \pm 0.10$ & 420 \\
$\mathrm{P}$ & $8.75 \pm 0.51$ & 700 \\
$\mathrm{~K}$ & $8.90 \pm 0.04$ & 4,700 \\
\hline
\end{tabular}

${ }^{\mathrm{a} M e a n}$ values \pm standard deviation of triplicate determinations; and ${ }^{\mathrm{b}}$ The mineral dietary reference intake for male adults as expressed in $\mathrm{mg}^{\mathrm{d}} \mathrm{d}^{-135,36}$. 


\subsection{Protein fractionation}

As shown in Figure 1, albumins are composed of many different polypeptides covering a wide range of molecular masses (18-94 kDa), whereas globulins (major fraction) are essentially represented by four major polypeptides $(18,34$, 40 , and $50 \mathrm{kDa}$ ). Prolamins show fractions ranging from 38 to $50 \mathrm{kDa}$ and the polypeptide composition of glutelins has fractions from 18 to $50 \mathrm{kDa}$. Several other protein bands were found in each of these fractions.

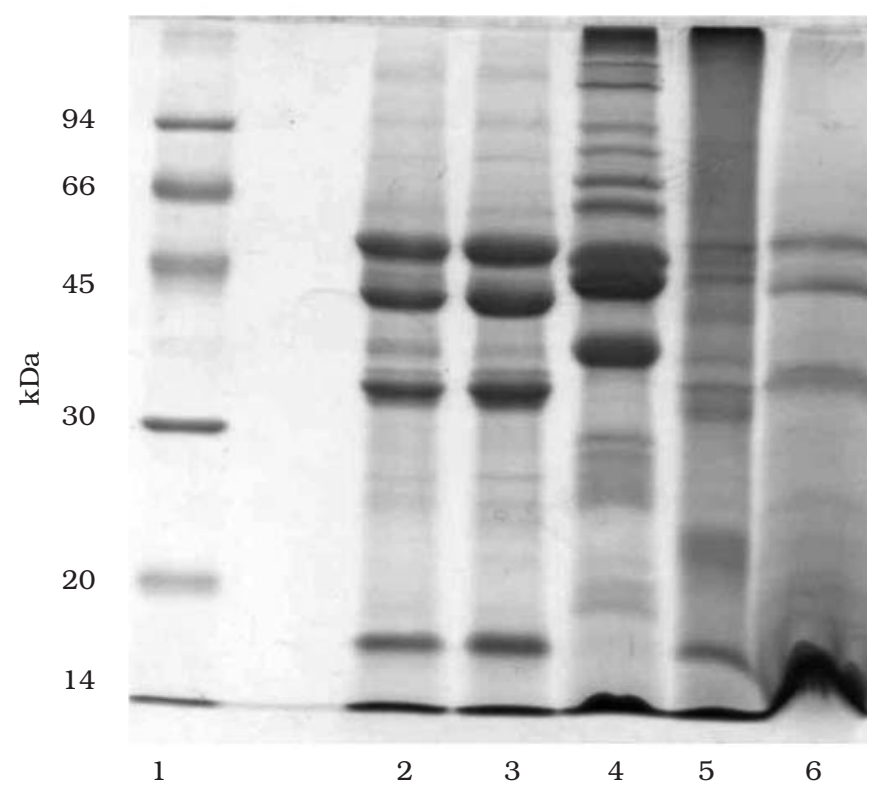

Figure 1. Polypeptide patterns of molecular mass marker (lane 1), crude extract (lane 2), globulins (lane 3), albumins (lane 4), glutelins (lane 5) and prolamins (lane 6) of sapucaia (Lecythis pisonis, Camb.) nuts.

The protein content of sapucaia defatted nut meal determined by BRADFORD ${ }^{4}$ was $66 \%$. In the present investigation, globulins made up the major protein fraction component of sapucaia nuts (58.7\%), whereas glutelins, albumins and prolamins accounted for $20.2,20.1$, and $1.0 \%$, respectively Table 4 . The globulin fraction showed a notably high protein concentration $(84 \%)$ when compared with the other fractions (data not shown), and was thus chosen for the purification and assays conducted in the present work.

Table 4. Protein fractions of sapucaia (Lecythis pisonis, Camb.) nuts, by solubility.

\begin{tabular}{cc}
\hline Protein fractions & $\%$ \\
\hline Globulins & 58.7 \\
Glutelins & 20.2 \\
Albumins & 20.1 \\
Prolamins & 1.0 \\
\hline
\end{tabular}

\subsection{Amino acid analysis}

The quality of seed proteins as sources of amino acids can usually be evaluated by comparing the $\mathrm{FAO} / \mathrm{WHO}$ recommended standards for essential amino acids ${ }^{8}$. As shown in Table 5, the proteins from sapucaia nuts contained adequate levels of phenylalanine, lysine, leucine, methionine, valine, and arginine, and the other amino acids were found in high or moderate amounts, based on the $\mathrm{FAO} / \mathrm{WHO}^{8}$ standards for children. The proteins also contained adequate amounts of essential amino acids for pre-school children and all the essential amino acids for adults. The concentration of tryptophan was not determined. When the amino acid content of sapucaia nuts is compared with that of animal proteins from eggs, cow's milk or beef, sapucaia nuts are found to be an excellent amino acids source.

\subsection{Antinutritional factors}

Protein quality is affected by antinutritional factors that interact with cells of the intestinal tract, such as proteinase inhibitors, lectins, and tannins, which reduce protein digestibility and amino acid absorption. Unless destroyed or inactivated by heat or by some other suitable treatment, these substances can exert adverse physiological effects when ingested by man and animals ${ }^{31}$. In the present study, no hemagglutination or inhibition were observed in any of the samples assayed (data not shown), revealing low or non-detectable levels of lectin and proteinase inhibitors and demonstrating that the nuts analyzed were free of these major antinutritional factors.

This is a relevant finding, because feeding raw soybean and many other legume products, which contain high levels of proteinase inhibitors, to experimental animals such as rats, mice and chickens leads to growth depression, pancreatic hypertrophy, and/or hyperplasia ${ }^{12}$ and a potentiation of pancreatic carcinogenesis ${ }^{15}$. Most of these compounds inhibit the digestive enzymes or react with essential amino acids, limiting the use of whole seeds in food products. Lectins bind to the intestinal mucosa, impairing digestion and absorption of nutrients ${ }^{20}$ and reducing protein digestibility by inhibiting digestive enzymes ${ }^{37}$.

\subsection{In vitro digestibility of globulins}

The in vitro digestibility of sapucaia nut globulins by mammalian digestive proteinases was carried out using trypsin, chymotrypsin and pepsin, separately. Incubation of purified globulins (Figures 2a, 2b and 2c) showed that trypsin digested the 18 and $66 \mathrm{kDa}$ fractions, but the globulins were resistant to hydrolysis by chymotrypsin or pepsin.

After heat treatment, however, the 50 and $66 \mathrm{kDa}$ fractions were digested by chymotrypsin and the 18,50 , and $66 \mathrm{kDa}$ fractions were hydrolyzed by trypsin, although no hydrolysis by pepsin was observed on SDS-PAGE (Figures 3a, 3b and 3c). Trypsin showed hydrolytic activity on both native and heated globulins. These results were compatible with previous findings that globulins are resistant to hydrolysis by pepsin ${ }^{2}$.

\subsection{In vitro digestibility by multienzymatic assays}

Figure 4 shows the SDS-PAGE patterns of native and heated globulins digested by multienzymes. The electrophoretic pattern of their in vitro digestibility is shown in Figure 5. 

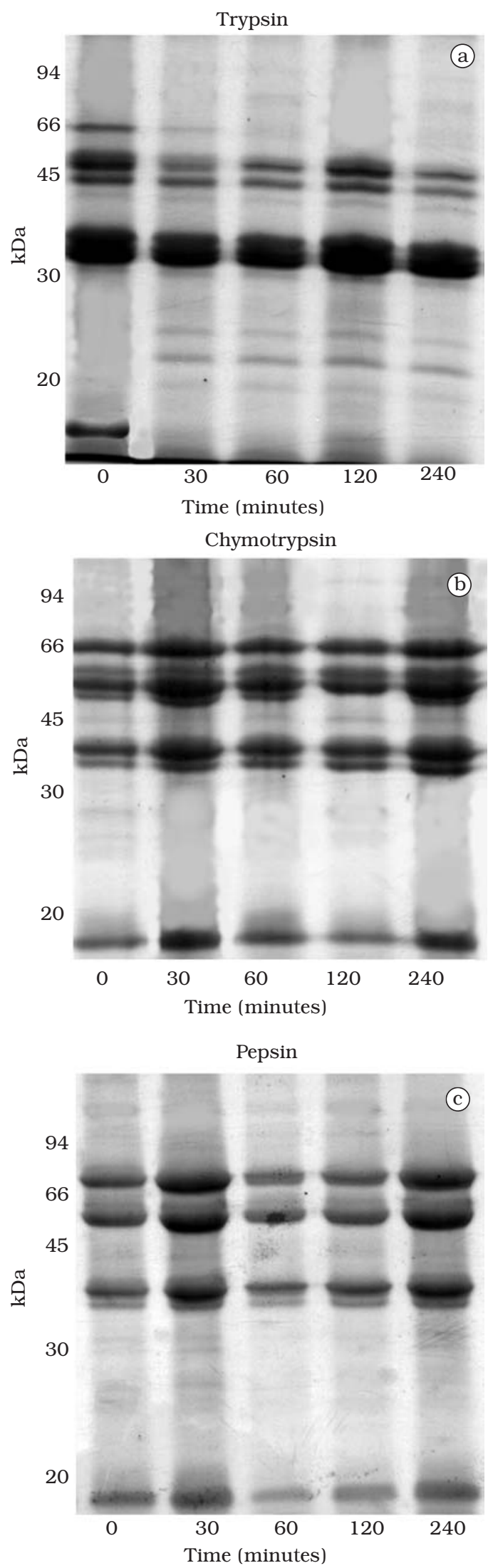

Figure 2. SDS-PAGE patterns of digestion of native globulins of sapucaia (Lecythis pisonis, Camb.) nuts by trypsin, chymotrypsin and pepsin, separately. a) Digestion by trypsin; b) Digestion by chymotrypsin; and c) Digestion by pepsin. Vertical numbers indicate molecular weight marker in $\mathrm{kDa}$. Horizontal numbers refer to times of digestion.
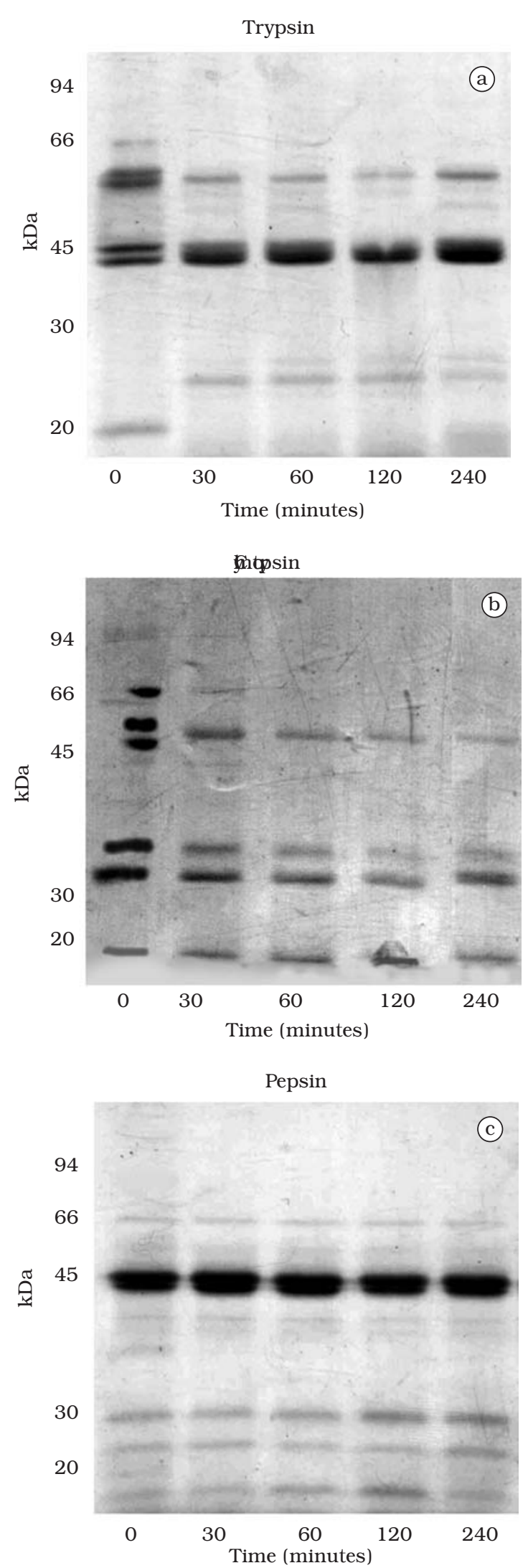

Figure 3. SDS-PAGE pattern digestion of heated globulins of sapucaia (Lecythis pisonis, Camb.) nuts by trypsin, chymotrypsin and pepsin, separately. a) Digestion by trypsin; b) Digestion by chymotrypsin; and c) Digestion by pepsin. Vertical numbers indicate molecular weight marker in $\mathrm{kDa}$. Horizontal numbers refer to times of digestion. 
Table 5. Amino acid composition of proteins from sapucaia (Lecythis pisonis, Camb.) nuts (mg.g ${ }^{-1}$ protein).

\begin{tabular}{|c|c|c|c|c|c|c|}
\hline & Albumins & Glutelins & Globulins & Prolamins & Total proteins & Requirement standard* \\
\hline Alanine & 10.0 & 32.2 & 44.2 & 1.4 & 87.8 & - \\
\hline Arginine & 2.4 & 57.6 & 108.6 & 0.5 & 169.1 & - \\
\hline Aspartate & 11.7 & 38.7 & 58.1 & 1.5 & 110.0 & - \\
\hline Cystine & - & 3.7 & 11.7 & - & 15.4 & $25^{* *}$ \\
\hline Glutamate & 36.4 & 83.8 & 153.3 & 1.8 & 275.3 & - \\
\hline Glycine & 39.0 & 43.2 & 73.2 & 1.7 & 157.1 & - \\
\hline Histidine & - & 7.4 & 11.8 & 0.1 & 19.3 & 19 \\
\hline Isoleucine & 2.7 & 10.6 & 15.8 & 0.4 & 29.5 & 28 \\
\hline Leucine & 1.0 & 42.8 & 69.0 & 1.0 & 113.8 & 66 \\
\hline Lysine & 28.4 & 20.7 & 31.9 & 1.1 & 82.1 & 58 \\
\hline Methionine & - & 30.1 & 59.2 & 0.3 & 89.6 & - \\
\hline Phenylalanine & 77.2 & 12.5 & 16.6 & 0.3 & 106.6 & $63^{* * *}$ \\
\hline Proline & 117.5 & 39.3 & 70.0 & 2.2 & 229.0 & - \\
\hline Seryne & 7.2 & 31.5 & 46.9 & 0.9 & 86.5 & - \\
\hline Triptophan & ND & ND & ND & ND & ND & 11 \\
\hline Tyrosine & 1.7 & 12.0 & 18.3 & 0.5 & 32.5 & - \\
\hline Valine & 4.7 & 22.4 & 34.1 & 0.8 & 62.0 & 35 \\
\hline
\end{tabular}

${ }^{*} \mathrm{FAO} / \mathrm{WHO}^{8}$; ${ }^{*}$ Cystine + methionine; ${ }^{* * *}$ Phenylalanine + tyrosine; Tryptofan was not determined - ND. Essential amino acids are in bold letters.

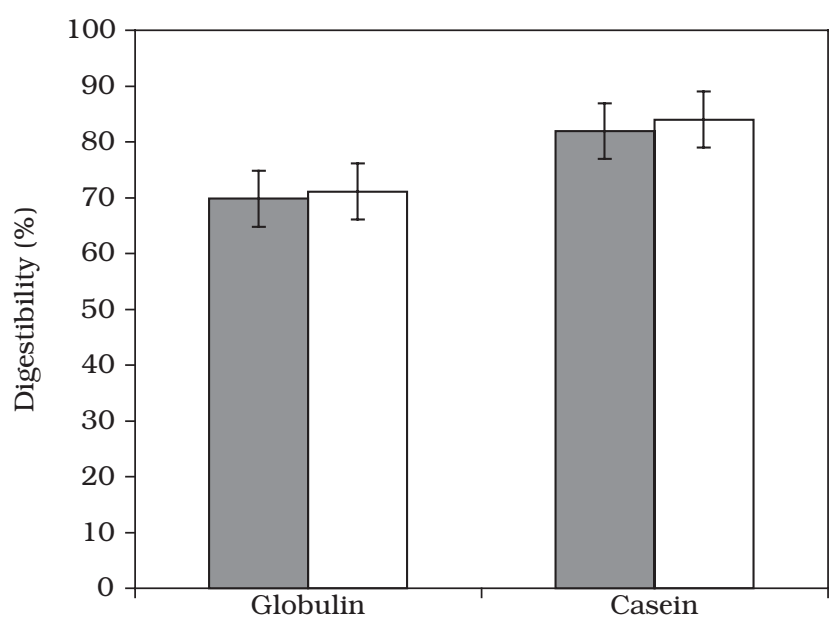

Figure 4. In vitro digestibility of sapucaia (Lecythis pisonis, Camb.) nut globulins by multienzymes (trypsin, chymotrypsin, and peptidase) in comparison with casein (mean $\pm \mathrm{SD}, \mathrm{n}=3$ ). Black columns: native protein; white columns: heated samples. Experimental error is indicated by standard deviation bars. The effect of heating on protein digestibility was statistically insignificant, according to ANOVA ( $p<0.05$ ).

Figures 4 and 5 reveal that the multienzymatic complex was efficient in digesting globulins. Digestibility was as high as $70.30 \%$ (Figure 4). Heating of globulins for 10 minutes led to an insignificant increase in digestibility, to $71.35 \%$. The increased digestibility of sapucaia globulins by multienzymes suggests that digestive enzymes may have a joint action, making all the bonds more accessible to proteases. The low increase in digestibility after heating suggests that sapucaia globulins can be ingested as fresh protein as the nuts do not contain antinutritional factors such as lectins and protease inhibitors.

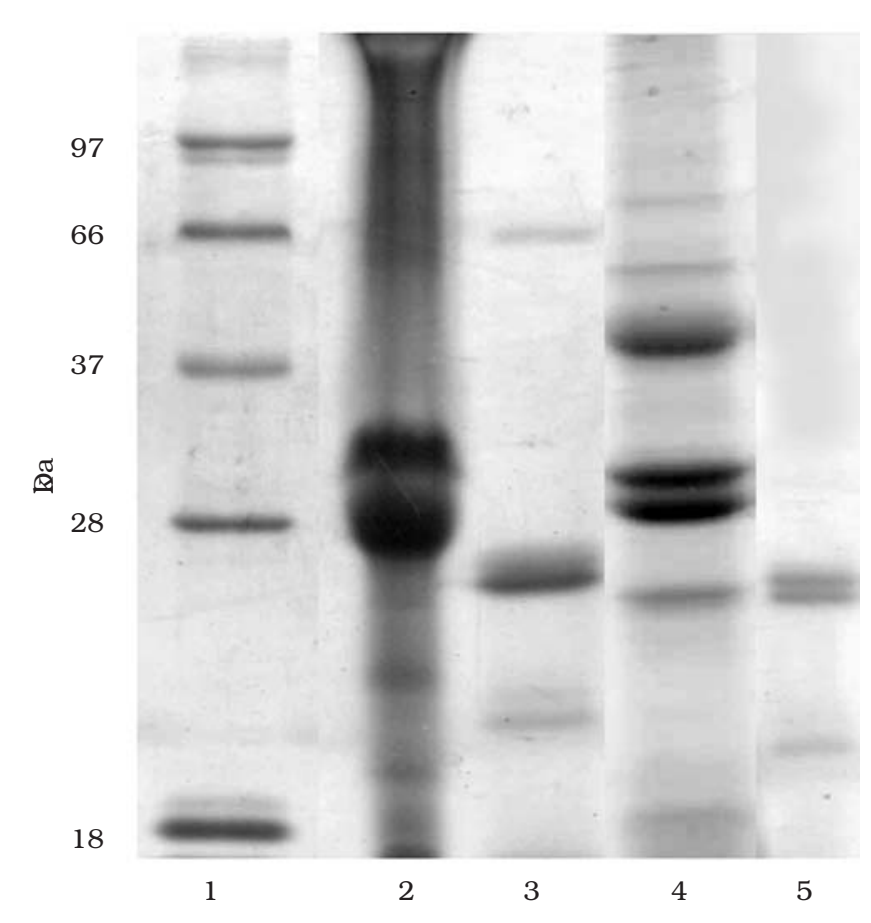

Figure 5. Electrophoresis showing in vitro digestibility of native and heated globulins of sapucaia (Lecythis pisonis, Camb.) nuts in a multienzymatic assay (trypsin, chymotrypsin, and peptidase); molecular mass marker (Lane 1), casein (lane 2), casein + multienzymes (lane 3), globulins (lane 4), and globulins + multienzymes (lane 5).

\section{Conclusions}

This study revealed that sapucaia nuts are a valuable source of proteins, with higher levels of essential amino acids, fatty acids and minerals than the recommended ones. No hemagglutinating or inhibitory activities were observed in any 
of the samples investigated, indicating low or non-detectable levels of lectin and proteinase inhibitors, thus demonstrating that sapucaia nuts are free of these antinutritional factors. In addition, the in vitro digestibility of globulins by a multienzymatic complex was significant. These observations suggest that sapucaia nuts may be a new source of proteins for human consumption, a potential functional and nutritional agent, and an economically important oil source.

\section{Acknowledgment}

The authors wish to thank FUNDECT (Fundação de Apoio ao Desenvolvimento do Ensino, Ciência e Tecnologia), of the Brazilian state of Mato Grosso do Sul; CNPq (Conselho Nacional de Desenvolvimento Científico e Tecnológico); PROPP-UFMS (Pró-Reitoria de Pesquisa e Pós-Graduação, Universidade Federal de Mato Grosso do Sul), and FINEP-MCT (Financiamento de Estudos e Projetos, Ministério da Ciência e Tecnologia) for providing financial support for this investigation. The authors are also grateful to Darli Castro Costa and Osmar Ferreira de Andrade for their technical assistance.

\section{References}

1. AMERICAN OIL CHEMISTS SOCIETY - AOCS. Official methods and recommended practices of the American Oil Chemist's Society. $5^{\text {th }}$ edition, Illinois, 1998.

2. ARAÚJO, A. H. et al. In vitro digestibility of globulins from cowpea (Vigna unguiculata) and xerophitic algaroba (Prospis juliflora) seeds by mammalian digestive proteinases: a comparative study. Food Chemistry, n. 78, n. 2, p. 143-147, 2002.

3. ASSOCIATION OF OFFICIAL ANALYTICAL CHEMISTS - AOAC. Official methods of analysis. $16^{\text {th }}$ edition, $3^{\text {rd }}$ revision, Maryland, 1997.

4. BRADFORD, M. M. A rapid and sensitive method for the quantization of microgram quantities of protein utilizing the principle of protein-dye binding. Analytical Biochemistry, v. 72, n. 7, p. 248-254, 1976.

5. BRASIL. Portaria $n^{\circ} 31$, de 13 de janeiro de 1998. Ministério da Saúde. Secretaria de Vigilância Sanitária. Regulamento técnico para fixação de identidade e qualidade de alimentos adicionados de nutrientes essenciais. Disponível em: $<\mathrm{http}: / / \mathrm{e}-$ legis.anvisa.gov.br/leisref/public/showAct.php?id=64 $>$ Retrieved, April 22, 2006.

5. BRASIL. Ministério da Saúde. Agência Nacional de Vigilância Sanitária. Resolução n. 482, de 23 de setembro de 1999. Diário Oficial da República Federativa do Brasil, Brasília, Secção I, p. 82-87 (Anexo 3 - Óleo de Amendoim), 13 out 1999.

6. ECAZOO. Cashew nutritional value. http://www.ecazoo.com/ cashews/default.asp. Retrieved April 22, 2006.

7. FAO/WHO. Report of a joint FAO/WHO expert consultation held in Bethseda, MD, USA. Dec 1989. Protein quality evaluation. FAO/Rome/Italy, 1991.

8. FIRESTONE, D. Official methods and recommended practices of the American Oil Chemists Society. $5^{\text {th }}$ edition. Champaign: AOCS, v. 2, 1998.

9. FRANCO, G. Tabela de composição química dos alimentos, $9^{\mathrm{a}}$ ed., Rio de Janeiro, São Paulo: Atheneu, 78-147, 1992.

10. FREIRE, M. G. M. et al. Isolation and partial characterization of a novel lectin from Talisia esculenta seeds that interferes with fungal growth. Plant Physiology and Biochemistry, v. 40, n. 1, p. 61-68, 2002.

11. GAllaheR, D.; SCHNEEMAN, B. O. Nutritional and toxicological aspects of food safety. FRIEDMAN, M. (ed.), New York: Plenum Press, p. 299-316, 1984.

12. GARCIA, V. A. et al. Trypsin inhibitor from Poecilanthe parviflora seeds: purification, characterization, and activity against pest proteases. Protein Journal, v. 23, n. 5, p. 343-350, 2004.

13. GILANI, G. S.; COCKELL, K. A.; SEPEHR, E. Effects of antinutritional factors on protein digestibility and amino acid availability in foods. Journal of Association of Official Analytical Chemists International, v. 88, n. 3, p. 967-987, 2005.

14. GUMBMAN, M. R. et al.Nutritional and toxicological significance of enzyme inhibitors in foods. FRIEDMAN, M. ed. New York: Plenum Press, p. 33-79, 1986.

15. HARTMAN, B.; LAGO, R. C. A. Rapid preparation of fatty acid methyl esters from lipids. Laboratory Practice, v. 22, n. 8, p. $475-476,1973$.

16. HEINRIKSON, R. L.; MEREDITH, S. C. Amino acid analysis by reverse phase high performance liquid chromatography precolumn derivatization with phenylisothiocianate. Analytical Biochemistry, v. 136, n. 1, p. 65-71, 1984.

17. HIANE, P. A. et al. Composição centesimal e perfil de ácidos graxos de alguns frutos nativos do Estado de Mato Grosso do Sul. Boletim do Centro de Pesquisa e Processamento de Alimentos, Curitiba, v. 10, n. 1, p. 35-42, 1992.

18. ___ Bocaiúva, Acrocomia aculeata (Jacq.) Lodd., Pulp and Kernel Oils: Characterization and Fatty Acid Composition. Brazilian Journal of Food Technology, v. 8, n. 3, p. 256-259, 2005.

19. HIGUCHI, M.; SUGA, M.; IWAI, K. Participation of lectin in biological effects of raw winged bean seeds on rats. Journal of Agricultural and Biological Chemistry, v. 47, n. 8, p. 1879-1886, 1983.

20. HOLLAND, B. In: The composition of foods. McCance and Widdowson's, Cambridge, UK, p. 8-9, 1994.

21. HORWITZ, W. Official methods of analysis of Association of Official Analytical Chemists. $17^{\text {th }}$ edition. Gathersburg, Maryland: AOAC, v. 2, cap. 41, p. 20, 2000.

22. HSU, H. W. et al. A multi-enzyme technique for estimating protein digestibility. Journal of Food Science, v. 42, n. 5, p. 1269-1271, 1977.

23. INSTITUTO ADOLFO LUTZ. Normas analíticas do Instituto Adolfo Lutz. $3^{\text {th }}$ edition. São Paulo, v. 1, 533 p., 1985.

24. LAEMMLI, U. K. Cleavage of structural proteins during the assembly of the head of bacteriophage T4. Nature, v. 227, n. 5259, p. $680-685,1970$.

25. LAJOLO, F. M.; GENOVÊSE, I. M. Nutritional significance of lectins and enzyme inhibitors from legumes. Agricultural and Biological Chemistry, v. 50, n. 22, p. 6582-6598, 2002.

26. MACEDO, M. L. R. et al. Purification and proprieties of storage proteins (vicilins) from cowpea (Vigna ungiculata) seeds which are susceptible or resistant to be bruchid beetle. Brazilian Journal of Medical and Biological Research, v. 28, n. 183-190, 1995.

27. ___ Trypsin inhibitor from Dimorphandra mollis seeds: purification and properties. Phytochemistry, v. 54, n. 6 , p. 553-558, 2000. 
28. MELLO, M. L. et al. Caracterização físico-química da amêndoa da castanha de caju (Anacardium occidentale) crua e tostada. Ciência e Tecnologia de Alimentos, v. 18, n. 2, p. 184-187, 1998.

29. PIMENTEL GOMES, F. Curso de estatística experimental. $14^{\mathrm{a}}$ ed. Piracicaba: F. Pimentel-Gomes Ed. 2000, 477 p.

30. RANGEL, A. et al. Biological evaluation of a protein isolated from cowpea (Vigna unguiculata) seeds. Food Chemistry, v. 87, n. 4, p. 491-499, 2004.

31. SALINAS, Y. G.; GARCIA, R. Métodos químicos para el análisis de suelos ácidos y plantas forrajeras. Cali: Centro de Agricultura Tropical, p. 83, 1985.

32. SGARbieri, V. C. Proteínas em Alimentos Protéicos - Propriedades-Degradação - Modificações. Livraria Varela, São Paulo, 1996.

33. TEIXEIRA, E. Frutas do Brasil. Disponível em: <http://www. alicesoftware.com/webs/treesnew/aweb/ td001/td00035.htm >. Acesso em: 20 fev. 2006.
34. THE NATIONAL ACADEMIES PRESS. Dietary reference intakes: elements. 2002. Disponível em: <http://www.nal.usda.gov/fnic/ etext/000105.html >. Retrieved May 11, 2006.

35. THE NATIONAL ACADEMIES PRESS. Dietary reference intakes: water, potassium, sodium, chloride and sulfate. 2004. Disponível em: < http://www.nap.edu> Retrieved February 12, 2006.

36. VADIVEL, V.; JANARDHANAN, K. Nutritional and antinutritional characteristics of seven south Indian wild legumes. Plant Foods for Human Nutrition, v. 60, n. 2, p. 69-75, 2005.

37. VAllilo, M. I.; TAVARES, M.; AUEDA-PIMENTEL, S.; BADOLATO, E. S. G.; INOMATA, E.I. Caracterização química parcial de Lecythis pisonis Camb. (sapucaia). Acta Amazônica, v. 28, n. 2, p. 131-140, 1998.

38. VALLILO, M. I.; TAVARES, M.; AUED-PIMENTEL, S.; CAMPOS, N. C.; MOITA NETO, J. M. Lecythis pisonis Camb. Nuts: oil characterization, fatty acids and minerals. Food Chemistry, v. 66, n. 2, p. 197-200, 1999. 